\section{THEORY OF BONDING}

Elementary Molecular Bonding Theory

By Peter G. Perkins. (Methuen's Monographs on Chemical Subjects.) Pp. viii + 183. (Methuen: London, October 1969.) $28 s$.

Chimists of all types and sizes have always becn interested in theories of bonding. In recent years, theoretical chernistry has advanced to a point where it is possible to claim that we understand the principles of atomic interaction. Current work is devoted to investigating quantitative aspects of the theory applied to particular molecules, and-all too rarely-to predicting new molccular structures and propertics. 'The established approach is through molecular orbitals, which reprosent many-electron structures in terms of one-electron functions; olectron correlation can be incorporated through "configuration interaction".

The aim of this little book is to present the modern theory of the chemical bond at an elementary level suitable for sixth-form pupils and for students at universities and tochnical colleges. This is a worthy but challenging objective. To reach it, an author needs to be tho complete master of his subject and to possess that rare gift of clear exposition.

This book begins with a discussion of early ideas of bonding and then introduces Schrödinger's equation and atomic orbitals. The third chapter is on valence bond theory, which could woll have been omitted. Tho fourth chapter is on molecular orbitals in diatomic mole. cules, and the fifth on molecular symmetry and orbitals in polyatomics. Finally, thero is a short summing-up.

There are a number of obscurities and inaccuracies that mar the book. On pago zero $\boldsymbol{e}$ is given with tho wrong sign. Many of the figures are poor (Fig. 2.18 should bo inverted, plane I in Fig. 5.6 fails to look anything like a mirror plane, and Fig. 3.15 is not easy to follow), and some have left-handed coordinate frames. Also, Mulliken's recommendation for the choice of axes to describe a molecule like $\mathrm{H}_{2} \mathrm{O}$ (the two-fold rotation axis should be $z$, with $x$ perpondicular to the molecular plane) has not been adopted. Nevortheless, the author has a pleasing style and his book is bound to bo useful to critical students. It may not, however, possess the clarity required of a book that is to make an important contribution to sixth-form teaching.

A. D. BuCRINGHAM

\section{REFINING PROCESS}

\section{Electro-Slag Refining}

By W. E. Duckworth and G. Hoyle. Pp. $x+178+44$ plates. (Chapman and Hall: London, November 1969.) $80 s$.

THi technology of stecl manufacture has developed rapidly in recent years to meet the increasingly more stringent requirements for clnser tolerance on composition and freedom from non-motallic inclusions. During the past decade, electro-slag refining (ESR) has progressed from the status of a laboratory technique to a manufacturing process for the production of high-grade steels, comparable in output to vacuum are remelting (VAR).

The process was first exploited in the Sovict Union, but is now in use in many countries. In Great Britain, a development unit was set up, under the leadership of the two authors, by the British Iron and Steol Rescarch Association, and this has now acquired an international reputation in electro-slag technology. The book gives a detailed and fascinating account of the cvolution of the process to the present stago of development. A treatiso, published in Russia in 1963, referred only to work carried out in the Soviet, Union. This is the first book to appear in the English language and the authors have attempted to collect an accurate account of the process in all the countries in which it is being applied.
The first half of the book describes the fundamental principles of the process and revicws present knowledge of the physical and chemical properties of the various slag compositions which have been studied. The conditions controlling the gas-slag-metal reactions are described and data are presented to aid in the selcetion of the optimum operating conditions for specific purposes. The research worker may regret the absence of consideration of the mechanisms of inclusion removal, but the authors have concentratcd on established facts and have avoided tho areas which are still controversial.

The second half contains descriptions of typical plant installations and operating techniques. Twenty-one tables list changes in composition and mechanical properties resulting from electro-slag refining of various grades of steel. The cconomics of the process are honestly cxamined and it is shown that present costs of ESR are comparable with those for VAR.

The authors state that they have tried to "present a roundod account of the state of knowledge" of ESR and "make it more widely known than is the case at present". 'They have succeoded in the first objective and anybody who reads the book cannot fail to be impressed by the potential of the process.

The book is well written, illustrated and presented. A minor criticism is the frequent reiteration of statements on successive pages in chapter three. C. BoDsworth

\section{CONTROLLED NUCLEAR FUSION}

Plasma Physics and Controlled Nuclear Fusion Research Vols. 1 and 2. (Proceedings of the 'Ihird International Conference on Plasma Physics and Controlled Nuclear Fusion Research held by the International Atomic Energy Agency at Novosibirsk, August 1-7, 1968.) Vol. 1: Pp. 998. Vol. 2: Pp. 836. (International Atomic Energy Agency: Vienna; HMSO: London, 1969.) Vol. 1: $191 s 8 d(\$ 23)$; Vol. 2: $162 s 6 d(\$ 10.50)$.

THE 1968 conference at Novosibirsk may well be remembered as the conference whore the ghost of Bohm diffusion was laid. Experimental evidenco reported at the conference showed that containment times of 50 to 100 Bohm diffusion times could now be achieved in laboratory plasma. Tho quest for a thermonuclear reactor is on the up again.

The two volumes contain a total of 134 papers of which 80 are in English, 37 in Russian and 10 in French. The Russian and French papers have an English abstract. Translations of the Russian papers have already been published in Nuclear Fusion. It is a great pity, for Western readers at least, that the Russian and French papers could not havo boen translated beforo publication, more so bocause these volumes should remain a standard reference for a fow years to come.

The first paper in the book is an extremely useful, but unfortunately rather short, reviow by Artsmovich of the present position in closed confinement systems. In another review, Buchsbaum argues for the continuation of study of mirror machines because of tho relative ease of experimentation. This view is to some extent reflected by the number of papers prosented at the confercnce on open ended machines. A feature common to most of the theoretical papers is that an effort is now being made to apply various theories to realistic geometries. Some of the experimental contributions already show that such a trend is most fruitful and will be even more so in the future.

Thaso two volumes are obvionsly going to be standard reference books for those interested in controlled nuclear fusion. 'They also contain a large amount of information, particularly on the theoretical side, which will be of use to those engaged in more general studics of the plasma state. As is usual for IAEA publications, the printing and general layout are excellent. GEORaE Rowlands 